\title{
The plural unification of sciences: the epistemological contributions of a perpetually dissatisfied discipline
}

\author{
Roberto Malighetti iD
}

Received: 14 January 2019 /Accepted: 31 January 2019 / Published online: 14 February 2019 (C) The Author(s). 2019 Open Access This article is distributed under the terms of the Creative Commons Attribution 4.0 International License (http://creativecommons.org/licenses/by/4.0/), which permits unrestricted use, distribution, and reproduction in any medium, provided you give appropriate credit to the original author(s) and the source, provide a link to the Creative Commons license, and indicate if changes were made.

\begin{abstract}
The article discusses the contributions of anthropology to the interdisciplinary dialogues on the scientific status of knowledge and on the relationship between the sciences. It attributes to the discipline a privileged position, founded on the distinctive character of ethnography: the development of a scientific discourse on humankind based on a personal experience. The intense involvements of the ethnographers in the research process and in the relations with their interlocutors - as well as the relativizing and cross-cultural disciplinary outlook - question the neutrality that other sciences idealize or can more easily take for granted and challenge the ideals of objectivity. The paper intends to contribute to the epistemological debate and to the understanding of the social role of science. It proposes the notion of objectivation (i.e. the study of the condition of the constitutions of scientific objects) to think the relations among the sciences and to propose a unifying perspective, albeit open, plural and contingent.
\end{abstract}

Keywords Anthropology · Epistemology · Method · Objectivity · Subjectivity · Objectivation $\cdot$ Interdisciplinary dialogue

\section{Introduction}

Fieldwork is an intense experience that questions the role of the researcher as well as the scientific status of knowledge. What other sciences can more easily take for granted, for anthropology becomes problematic because of the greater existential

R. Malighetti $(\bowtie)$

Dipartimento di Scienze Umane, Università degli Studi di Milano-Bicocca, Piazza dell'Ateneo Nuovo 1, 20126 Milan, Italy

e-mail: roberto.malighetti@unimib.it 
involvement of the ethnographer in the research process and in the relations with the interlocutors. The point is efficaciously summarized in Lévi-Strauss' characterization of anthropology as "without a doubt unique in making the most intimate subjectivity into a means of objective demonstration" (Lévi-Strauss, 1968:26).

The mimetic adoption of models taken from the natural sciences and the use of quantitative methods have not succeeded in resolving the original incompatibility between subject, method and object, conceived as an ideal by modernity. Moved by what Foucault calls "a perpetual principle of dissatisfaction" (Foucault, 1971: 371) the anthropology of the last quarter of the twentieth century has used the contributions of the philosophical and scientific thoughts to rethink its epistemological foundations. Reconstructing the methodological and epistemological paradigms through which anthropology has shaped its own knowledge, the text critically analyzes the ethnographic practice, from the evolutionary beginnings (Tylor, 1889) and the Malinowskian ethnographic revolution (Malinowski, 1922) to the interpretative and post-modern turns (Geertz, 1973; Clifford, Marcus 1986) and the paradigms of embodiment (Csordas, 1990, 1994; Ingold, 2000). The unrepeatability and contingency of the ethnographic process as well as the relativistic elective affinities, induced by the transversal or cross-cultural disciplinary outlook, are valued for their potentiality to solicit a consideration of the problem of opacity as a constitutive element of any scientific effort (Glissant, 1997; Herzfeld, 2018).

The article seeks to overcome the modern conceptions of the sciences and the resulting forms of positivist monism and the dichotomies of the German historicist tradition (Naturwissenschaften VS Geisteswissenshaften). It proposes the notion of objectivation - the analysis of the conditions of the constitution of scientific objects (Borutti, 1999) - to configure the relations among the sciences and to think a possible unification of them, albeit open, plural and contingent (Author, 2016; Author, 2018).

\section{Objectivity}

The anthropological appropriation of the modern concept of science and its subordination to principles that originated in seventeenth-century empirical and rational knowledge of astronomy and physics, allowed the discipline to define its specific epistemological and methodological identity. Evolutionist comparativism, the practice of participant observation, the use of quantitative methods and of formalized languages produced a concept of objectivity that was based upon an irreparable opposition between subject and object and resulted in a methodological and epistemological elimination of the subject.

As explained by Heidegger (1938), the epistemological basis of modern science resides in a double movement. On the one hand, it unfolds the world of 'external' objects (Gegenstand), subsumed under the laws of physical causality. On the other, ontologically separated from it, it places the subject as the ideal pole of a set of rational faculties, an abstract and impersonal 'I' that stands as 'legislator of nature' by virtue of its transcendental character. The neutrality of the method is rooted both in the object, the data (past participle of the Latin verb dare meaning to give, 
to pose), and in the subject, preliminarily de-subjectivized. This double extraneousness is at the basis of the universal and transitive character of the scientific method (from the ancient Greek metà, 'behind' and hódos, 'way'). Once the subject is eliminated by the method, the social data become real objects found in the world, accessible to direct and neutral observation, ready to be transcribed in the denotative and referential language of science.

On this basis modernity generated a normative system of thought, articulated by the different epistemological principles that inaugurated the scientific method: Bacon's inductive model; the Galilean union of observation, experimentation and mathematization of nature; the Newtonian experimental and causational classical mechanics; the Cartesian metaphysical systematization of this form of rationality, based on the dualism between res cogitans and res extensa and on the subsequent conception of knowledge as representation (Rorty, 1980).

Modern science gave rise to the assumption of an abstract and timeless thought, devoid of historical and social mediations. That assumption was originally grounded in the Baconian critique of the individual and social idola, in the Cartesian methodic doubt and in the Spinozan de intellectus emendatione. It removed knowledge from the conditions of its production and from its social and cultural roots, much as the eyes see but are not themselves constrained by being seen. It introduced the prominent orthodoxies that still hold firm in the understanding of what science is: the myth of a univocal and fixed method; the rigid separation between subject and object, theory and data, and theory and observation; the search for a perfect language, purified of subjective references; and the mystical ideal of truth.

The artifice of the logico-mathematical formalization introduced by the European modern sciences was initially adopted by anthropology and translated into anthropological terms through the comparative method founded on statistical correlations and concomitant variations (Tylor, 1889) and, later, through the method of statistical documentation using concrete evidence (Malinowski, 1922). It yielded a formal way of thinking that shaped the development of anthropological method, from the six editions of Notes and Queries on Anthropology (BAAS, $1874,1892,1899,1912,1929,1951)$, to Lévi-Strauss' structuralism and to the contemporary forms of neo-positivism (King, 2014; Steinmetz, 2005; Turner, 1985). Science thus understood is a form of rationality that attains its results by generalizing induction. It relies on the normativity of a formalized language, refined so as to escape the ambivalence of perceptual experience and the qualitative thickness of the relationship between researcher and research material. Although this approach still takes the subjective experience of the ethnographer as central to the research process, it subsumes it under the quantitative domain of classification and nomenclature.

In this epistemological framework, ethnographic practice, prosaic and descriptive, is necessarily unreflective. It is chronologically and hierarchically subordinated to the theoretical anthropological effort that legitimizes it. It is based on the positivistic separation between the factual and the theoretical moments that marked the development of anthropology. At the onset of the discipline, this perception gave rise to the division of labor between "official correspondents" in the field 
(Fison, Gillen, Howitt, Spencer,) and "armchair theorists" at home (Frazer, Morgan, Tylor), the latter working for institutions such as the Ethnological Society and the Royal Anthropological Institute in London (Stocking, 1983).

Over time, the method of participant observation, although incorporating ethnography and anthropological theory in one and the same body, reproduced the analogous logic of an independent and immediately given objectivity and the separation between the gathering of the facts and their theorization. It involves a contradictory balance between subjectivity and objectivity, between the direct involvement in the activities of the native and the simultaneous maintenance of the detachment required by the scientific observation. The personal experiences of the ethnographer, albeit recognized as central to the research process, were thus severely limited by the impersonal standards necessitated by scientists' insistence on the primacy of objectivity.

This methodological rationale was renewed by Lévi-Strauss' stratigraphic arrangement of ethnography, ethnology, anthropology. In his schema, ethnography refers to the first stages of the research, especially observation and the collection of specific data; ethnology corresponds to the contextual description; and anthropology is the truly scientific step, grounded in the development of theoretical generalization (Lévi-Strauss, 1958:388-390).

The autonomy of the factual level remains an implicit and unanalyzed assumption of this methodology. The epistemological question inaugurated by Descartes focuses on the relationship between reality and its representation according to an ideal of immediate transparency and direct transcription. It does not interrogate the givenness of the primary data, which are instead regarded as factual protocols that are independent of observers and their theoretical positions. Truth thus conceived depends on a concept of verification that measures the correspondence between a representational view of knowledge and a comprehension of reality as a collection of objects. In this perspective, however, the epistemological problem remained the intractable question of how to reduce the theoretical level to the observational one.

According to this nomological paradigm, the objects receive their identity by belonging to a class of individuals equivalent and homogeneous in their essential properties. There are no individual events but only mutually replaceable cases, conceived extensionally through their class membership. They are reduced to a univocal standardized description and deduced from a theory that assigns each given entity to a formal class. Malinowski understood the 'natives' point of view' as 'stereotyped manners of thinking and feeling' and not as 'what A or B may feel qua individuals, in the accidental course of their own personal experiences' (Malinowski, 1922:17) Similarly, Radcliffe-Brown's natural science of society (1957) held that the scientific study should not worry about 'the particular, the unique... the actual relations of Tom, Dick and Harry or the behavior of Jack and Jill'. Rather, science should deal 'only with the general with kinds, with events which recur.... what we need for scientific purposes is an account of the form of the structure' (Radcliffe-Brown, 1940:4).

Under the hegemony of positivism, the anthropological tradition could not give satisfactory attention to what its practitioners all recognize as the real force and hallmark of the discipline and the experiential basis of those fieldwork rites de passage that legitimize the identity of the anthropologist. For a long time fieldwork 
has been acknowledged as a skill that is learned with practice and total immersion (Epstein, 1967), or defined through a generic appeal to common sense (Beals, 1970; Beattie, 1965). Emblematic in this regard is the account provided by Evans-Pritchard (1937) on the advice he received from the leading ethnographers of his time before going to East Africa. Westermarck, more tersely, suggested that one should not "converse with an informant for more than twenty minutes, because at that point if you're not sick, it will be him'. Haddon said he 'always had to behave like a gentleman'. His teacher, Seligman, gave as his best advice that one should 'take ten grains of quinine every night and keep away from the women'. Malinowski warned him 'not to be a bloody fool' (Evans-Pritchard, 1937:240).

As Descola suggests (1993:480), while historians mention their archives, and sociologists and psychologists describe the questionnaires and protocols, anthropologists have seldom exhibited the processes whereby they actually construct their knowledge. Hidden behind a 'conspiracy of silence' (Berreman, 1962) that serves to protect their truths and to suppress the anxieties of their work (Devereux, 1967), they have too often excluded from their published texts the pragmatic context of the comprehension, the intersubjective foundations of fieldwork, and the ways in which they developed the type of knowledge they propose as factual.

The classical monographs reduce their subjects to the anonymity of a transcendental author and a generalized conception of the interlocutors. Their positive approach to objectivity does not take into consideration the trials and misunderstandings, the difficulties, the intuitions, the doubts, the strategies, the conflicts and all that complex whole of feelings, qualities and occasions that identify the specificity of the anthropological way of working (Agar, 1985; Jamin, 1986; Kilani, 1994). They present as intuitively evident what instead requires much time-consuming synthetic elaboration: the vain search for 'exaggerations' (Boon, 1982), for exceptional events or interesting dialogues, the pursuit of annoyed informants who are often unable to answer to he anthropologist's questions or reluctant to take on themselves the responsibility for enunciating larger principles explicitly. Fieldwork activity is relegated to anecdote and confessions or confined to notes, prefaces, appendixes, or publications that are distinct from scientific works. Such 'secondary' works are published under pseudonyms (Bowen, 1954) or in very informal idioms (Barley, 1983; Beattie, 1965; Dumont, 1976; Turnbull, 1961).

Notably, it was Valetta Malinowska's initiative to publish her husband's diary (Malinowski, 1967) posthumously that revealed how ethnography became an epistemological problem at the very moment in which it established itself as methodologically indispensable and secure. The text exposes the artificiality of the operation of objectivation of the subject both as a knowing actor abstracted from experience and identified with a logical function and as a known element within a larger entity such as a society, a culture, or a group of informants. The research practices that emerge from the diary 'in the strict sense of the term' clarify the problematic nature of this assumption at the very origin of the project of anthropological modernity. They testify to an ambiguous and contradictory oscillation between subject and object - that is, between the abstract persona of 'the ethnographer' as a neutral observer and the empirical 'I' of the deeply involved human being. The diary shows that Malinowski's actual fieldwork activities could not resolve the precarious equilibrium 
between observational objectivity and subjective participation and thereby conclusively demonstrates that disjunctive intransigence that the 1922 text tries to impose on the reader as science. The project of participant observation did not succeed in combining subjective experience with objective detachment (Duranti, 1997; Paul, 1953). Malinowski's research activities remained subordinated to an objectivist imperative that favored the practice of observation and marginalized the methodologically innovative element of participation. He did not grasp the 'native's point of view' from empathic experience but from a statistical calculation of variables. The analysis of the work in the Trobriand Islands shows that the subject is an effect of the method rather than its foundation (Author, 2016).

The modernist perspective gave rise to two main ways to think the problem of the epistemological status of the sciences, both linked to the notion of given objects (nature, society). On the one hand, it produced the unification of the sciences as required by a monological positivism that is based on an independent and alienated objectivity and on a consequent loss of ontological diversity. A rigorous and methodologically controlled theoretical syntax is deemed responsible for the representation of a sense that is already 'out there' and unproblematic. The neo- empiricist program of a meta-linguistic and normative union of knowledge fuses logico-mathematical with empiricist and with the observational basis of meaning (Carnap, 1935; Hempel, 1965; Neurath, 1932).

On the other hand, the antipositivist criticism (Methodenstreit) of German historicism introduced a rigid opposition between the sciences of nature (Naturwissenschaften) and the sciences of the spirit (Geisteswissenshaften). Inaugurated by the dichotomy (Droysen, 1868) between explanation (Erklären) and understanding (Verstehen), it has been interpreted by the Diltheyan (Dilthey, 1883) view of the different configuration of the 'psychic' intuitive relationship (Erlebnis) between subject and object (ontological union VS separation), and then adumbrated to the methodological difference between idiographic and nomothetic sciences proposed by Windelband (1894).

Neither of these conceptualizations can adequately resolve the interrelations among the sciences or the articulation between the factual and the theoretical. Positivism and neopositivistic monism remain prisoners of the separation between the syntactic and the semantic levels. They establish two forms of truth: an analytical truth (empty form, unrelated to experience) and a truth referring to the observable predicates of things (pure content without form). The neopositivist epistemology fails to connect theory and experience and to relate the theoretical vocabulary of science to the terms of observation. It cannot problematize the inherence of form to content, the action of the first in the production of the second, and, more generally, the conditions of the visibility of facts. The Methodenstreit dispute merely reinforces the rigid opposition between idiographic and nomothetic sciences; between explanation and comprehension; between empirical phenomenon and law; and between the logic of norms that subsume particulars and individual logic in its irreducible specificity (Borutti, 1999:23-83).

\section{Subjectivity}

The opening of anthropology to hermeneutics (Geertz, 1973; Clifford, Marcus 1986) allowed the discipline to emancipate the question of the scientific status of 
knowledge from the mimetic adoption of the modern concept of science and from the methodological assumption of objectivity. It provided a key for rethinking the relationships between subject and object and the articulation of the research experience with scientific generalization.

Hermeneutics overcomes the metaphysics of givenness in favor of a constructivist point of view that considers how knowledge builds its referents, forming and shaping the phenomena under examination. On the one hand, it conceives the subject as a real agent, ontologically grounded in a specific knowledge and culture and not as a paradigmatic or a 'neutral' substance. On the other it conceives the ob-iectum (a Latin word meaning 'thing put in front') as the effect of a construction produced by the technical device of schematization and modeling. The object is not Ding, substantial data, immediately found 'out there' (Gegen-stand), endowed with properties independently of the knowing subject. Rather it is Sache, the question, what is under consideration. From this perspective, to present things as subsisting 'in themselves' becomes a particular determination to which a subject decides to subject them and through which that subject is able to relate to them (Gadamer, 1965).

The circular relationships between subject and object transform what for positivism is a limit on a necessary condition for knowledge: the interpreting subject, being ontologically bound to a linguistic (Heidegger, 1927) or historical (Gadamer, 1965) horizon, is able to establish a knowing relation with the object. This approach deftly re-designs a subject that the modern ideal of science has removed by means of an improbable epochè and empathic relations, as an intersubjective being, active in the process of the construction of the natural and cultural worlds. To be open to Otherness does not imply an annihilation of the self based on the objectivity of the method. On the contrary, it is through the knowledge of one's positions that the Other is manifested and acquires meaning.

Going beyond objectivism and subjectivism (Bernstein, 1983), hermeneutics recognizes a complicity between subject and object, grounded by Gadamer (1965) in the notions of co-belonging and of the fusion of horizons. It is placed in the intersubjective ontological structure of being-in-the-world. Pre-comprehensions are the inevitable constituent elements of the horizon from which the subject interprets reality and the language that gives meaning to the world.

Hermeneutics offers a useful pragmatic framework within which to think through the ethnographic encounter. It recommends an open approach that seeks to problematize the situation of the research process, disturbing the neutral equilibrium between subject and object. It invites the ethnographer to probe the conditions of fieldwork, the micro-processes of everyday life, and the translation between cultural and linguistic borders. Hermeneutics requires us to study the interrelations and the mutual determinations among the different interlocutors, taking their multiple contexts and variegated world views, their different strategies and forms of rationality, into account. It proposes a phenomenology of the construction of knowledge that encourages us to question the theoretical models, the prejudices and the starting hypothesis. It compels us to examine the complex negotiations, the reciprocal manipulations, and the adjustments among the categories and world views of the various interlocutors; moreover, it forces us to illustrate how 
informants build their knowledge and communicate it in relation to the manner in which anthropologists, for their part, gain access to it.

The dynamics of the research process and of its textual realization build the anthropological object by bringing together a complex set of negotiations: between the anthropologist and the interlocutors in the field, and among the interlocutors themselves; between the different sources of information, oral and written; between the anthropologist, the theoretical models employed, and the scientific community; between the anthropologist as actor and the anthropologist as the object of self-reflection through time and through the vicissitudes of personal and professional activity; between the anthropologist, the text, and the readers. The ethnographic materials are complex and articulated, 'constructions of constructions', interpretations of interpretations' (Geertz, 1973), consisting in the textualization of what the ethnographer records, of what the ethnographer is able to understand, and of what the interlocutors want to tell us, or can tell us, of what they understand (Sperber, 1982:26).

The self-reference that forms an integral aspect of the notion of hermeneutic circularity, implies a reflexive approach to knowledge. Access to the Other is mediated by one's own ontology and by one's own belonging to a linguistic (Heidegger, 1927), historical (Gadamer, 1965), or textual (Ricoeur, 1983) community. Reflexivity roots anthropologists in their own knowledge and makes their experience the basis of the discipline and of its method. It asks anthropologists to represent the social realities under investigation through the prism of their lived experience and to see the ethnographic practice as part of the analysis and of the work of textualization. From this point of view, anthropological texts cannot avoid presenting the processual nature of the construction of anthropological knowledge, the negotial negotiated nature of anthropological understanding, or the dialogical relation between the conceptual models of anthropologist and those of the various interlocutors. These elements constitute a polyphonic textual reconstruction that is always precarious and contingent (Author, 2008a; (Author, 2014b).

Ethnography exists inside negotiated spaces in a state of constant conceptual effervescence. In these arenas, where different actors confront, cooperate, collude and contend, actors are inevitably positioned (Rosaldo, 1989): their ideas are shaped by a mutual recognition that determines the specific quality of the discourses. The authority the ethnographers establish in the field authorizes and selects their discourse and thereby provides the foundation for their authoriality (Author, 2007a; (Author, 2014a). What informants communicate through dialogue is told not from the center of their world but from the liminal space of the encounter. What they say to the anthropologist does not consist of 'cultural truths', simple expressions of ideas already present in their minds. Rather, it includes detailed answers to the ethnographer's questions and reactions to the ethnographer's presence. Anthropological facts are not logically prior to their interpretation, dictated by perfectly competent and neutral spokesman of a timeless and undifferentiated cultural essence 'by virtue of special knowledge, skills, authority and quality of intellect or character' (Casagrande, 1960:37) and then, at a secondary level, explained and contextualized. The interlocutors are original interpreters of their own culture, real people, with their own idiosyncrasies and peculiarities and with the limits of their 
knowledge determined by experience. Not only is the native's point of view but a single perspective among a host of possibilities, but, above all, it is always mediated and pre-oriented. Once the natives are constructed as informants, their voices are already edited by anthropological understanding and writing. Anthropology is the product of a negotiation, conducted from the anthropologist's point of view, and with the anthropologist's opinions inscribed in the history of the social actors and in the temporality binding observer and observed (Author, 2008b).

Understanding cannot simply consist in placing the native's point of view in a domesticated heteroglossia (Bakhtin, 1986), in a difficult polyphonic orchestration, or in a neutral and innocent pidgin language. To disperse and to distribute the ethnographic authority among informants means denying the scientific status of the discipline. Anthropological interpretations are, by their very nature, different from the natives' own reports: their effectiveness is precisely based on this heterotopia (Hastrup, 1993). The strength of interpretation lies in the gap that allows the analyst to construct meaning. The purpose of anthropology is to achieve an understanding that differs from the immediate intention of the actor. The analytical immersion in the private world of the interlocutors is scientific to the extent that it is able to translate the private language of the natives into the public and specialized language of anthropology - the emic into ethical notions, the experience-near into experience-distant concepts (Geertz, 1973; Kohut, 1984), abnormal discourses into normal discourse (Rorty, 1980), the standard into the non-standard (Kuhn, 1962).

Any translation involves an irremediable difference between the original discourse and its reproduction. It is not a pure copy but a mediation determined by a difference between languages that cannot be resolved through naive appeals to fidelity (Gadamer, 1965). As Benjamin wrote, 'every translation is only a somewhat provisional way of coming to terms with the foreignness of the languages' (Benjamin, 1968:74). It is based on the gap between different universes of discourse and it is characterized by a form of incommensurability and entropy (Feyerabend, 1975; Geertz, 1983; Kuhn, 1962; Quine, 1960). In epistemological terms, the 'untranslatable' (Affergan, 1999) is the Kantian limit that configures the space of the cognitive relationship with the Other. Without this limit, without the background (Hintergrund in Wittgenstein's terms) that roots us in our culture and knowledge, we cannot experience the world (Borutti, 1999:166).

Untranslatability qualifies the hermeneutic endeavor as an endless effort and an interminable oscillation of interpretations. It grounds the movement of comprehension on the constant renewal of the initial project and of the preliminary hypotheses on the basis of the more immediate sense that the knowing process exhibits. Hermeneutics founds knowledge on the continuous adaptation of pre- comprehensions to the forms of life the ethnographer seeks to understand. This complex intellectual bricolage is deeply embedded in the dynamics of everyday life and in the researchers' commitment to constantly correcting their perspectives. It conceives of theoretical elaboration as a dynamic and open process, productive of new projects and always capable of reaching new accommodations with reality. It compels the anthropologist to examine and solve the methodological, theoretical and ethical problems that arise in the context of the interactions with interlocutors both in the field and at home. Deformation, errors, misunderstandings, and failures become the 
heuristic tools of research and the foundation of reflexivity. As such they qualify the scientific effort as empirical, and, as Herzfeld maintains, 'realistic' (Herzfeld, 2018).

If this opacity is not put at the heart of the research processes, the hermeneutical movement of interpretation becomes impracticable and contradictory, entangled in a cognitive optimism that endorses the improbable idea of perfect linguistic translations and the possibility of a complete knowledge of the world. This is the trap into which many anthropological appropriations of hermeneutics have fallen. The ethnographies of the founding fathers of interpretive approaches fail to realize this sense of hermeneutic circularity and to emancipate themselves from the limits that they denounce in their theoretical reflections. They remain trapped in the dualism of subject and object, overwhelmed either by idealized anthropologists placed at the center of the scene (Crapanzano, 1980; Geertz, 1973; Rabinow, 1977), swallowing their interlocutors in crude generalized portraits ('the Balinese', 'the Javanese'), or by natives speaking in a monological inverted dialogue that occupies the totality of the field (Dwyer, 1982). They fail to expose the actual, pragmatic dimension of fieldwork, the interrelations between ethnographer and interlocutors, and to indicate the articulation of the processes through which meanings are produced and shaped by the anthropologist. The object is conceived as 'given', presented without mediation and organized linguistically in a set of all-encompassing meanings. It is dominated by an aspiration to total authenticity and transparency that relies on the primacy of representation and takes for granted that the cultural text is always translatable and is always linguistic.

A similar cognitive optimism invests the attempts made thus far to connect hermeneutics with phenomenology and to elaborate a corporeal knowledge that emerges at a practical-pragmatic level beyond a logocentric self-sufficiency. Anthropologies based on the body (Csordas, 1990, 1994; Ingold, 2000) reproduce the Malinowskian conundrum of how to link participation with theorizing. They take for granted the question of how to translate the physical effort of the researcher into the general purpose of fieldwork, which is intellectual, theoretical, and scriptural. The claim that the Other can be comprehended through ethnographic embodiment is an inverted form of sublimation of the research practices and of the body, a reflection of the idealization of language we typically find in interpretive anthropology. To be irreducible to a text does not mean transparency in experience. From Heidegger's hermeneutical horizon, the experience that accompanies and manifests the Other is not empathy but anxiety (Angst). And anxiety is an index of opacity, not of transparency (Author, 2016).

\section{Objectivation}

The concept of objectivation and its suggestion to examine the constitution of the scientific objects (Borutti, 1999:13-21), is a useful analytical tool for pondering the epistemological status of the sciences and their interrelations. It offers a perspective that conjoins a range of theoretical schools: hermeneutics, the philosophy of science, constructivist epistemologies, and analytic philosophy. It conceives reality in a non-representative way and in conformity with a non- extensional logic: 
verum est factum (Vico, 1744), 'the truth is made' (factum past participle of the Latin verb facere: 'what is made'). The notion allows to think the complex links among subject, method, theory and object, through the analysis of the modeling mechanisms - that is, of the way the models construct their objects (Black, 1962; Hanson, 1958; Kuhn, 1962). It thereby proposes to adopt a conception of science as a phenomenon-technique: a technique for the production of phenomena (Bachelard, 1940).

From this point of view, theory assumes the function of the Kantian schema: a model that presents and constructs the data (Vorstellung in Kantian and Wittgensteinian terms: vor 'before, in front' and stellen 'to put, to place'). It is not imaginative or figurative representation of the object (Darstellung). The function of the theoretical model is objectifying and poietic (from ancient Greek poiein meaning 'to make'). ${ }^{1}$ It displays possible configurations of events and the inherence of form in content, that is, the manner in which objects are presented by their form.

This approach develops the study of the internal criteria of knowledge, following the Kantian sense of the transcendental: it examines the conditions of possibility for knowing objects given by theory (phenomenon) and not as objects in themselves (noumenon). It allows us to probe the procedures, whereby objects are constructed, that are common to all sciences: instruments of symbolic writing, of demonstration and of formalization; analogic mechanisms of schematization and modeling (the micro-model of physics, the games model in economics, the model of the text in anthropology, the model of the document of in ethnomethodology); and rhetorical and argumentative apparatuses for shaping discourse and communication (Borutti, 1999:15).

The interaction between form and content, that Cassirer (1953) called the symbolic function (das Symbolische) qualifies not only the human or social sciences such as anthropology or sociology, where linguistic or the statistical modeling prevail, but also physics and those other forms of knowledge in which modeling is performed through the adoption of mathematical structures. Poietic perspectives have been applied to different scientific discourses: sociology (Berger, Luckman, 1966; Giddens, 1984; Goodman, 1978), mathematics (Ernest, 1998; Restivo, 1992), physics (Pickering, 1999), neuroendochrinology (Latour, Woolgar, 1986) psychology (Kelly, 1955; Piaget, 1967; Watzlawick, 1984), education (Kincheloe, 2005) marine biology (Helmreich, 2009), and biotechnologies (Rabinow, 1997).

Contemporary science delivers an uncertain and complex image of a world of non-absolute and non-localized objects. It provides a reality alternative to the simple Euclidean extended bodies, defined by a metric space, well circumscribed and clearly defined in speed and location. Not only the objects of the so called soft sciences, but also those of the hard sciences, such as the micro-objects of subatomic physics (protons, neutrons, electrons, quarks), cannot be conceived from an individualizing point of view. In other words, they cannot be taken as simple evidence in a Newtonian sense, demonstrations of an underlying truth that can be connected to each other in causal terms by means of the self-evident categories of mechanics

\footnotetext{
${ }^{1}$ The term poietic is used following Ricouer's interpretation of Aristotle Poetics. For a critical discussion of the translation of the Greek term, see Herzfeld 2016:165-171, 175-178.
} 
(mass, force, and motion). As Borutti has properly shown (Borutti, 1999: 13-20), the objects of the sciences (the genes of biology, the myths of anthropology, the quarks of physics, the institutions of sociology) cannot be observed and represented from a position of neutrality. They are artificial constructs, the precipitates of complex operations of framing and modeling. They result from theoretical and technical procedures that are themselves what make possible the visibility and the knowability of the world. Scientific objects have no existence prior to the inevitable alteration of the parameters produced by the knowing subject. They are theoretical places or nomological objects (from the ancient Greek nomos 'law'): objects given, not discovered, by the laws enunciated by scholars.

Quantum mechanics maintains that in each measurement there is an interaction between the object and the instrument, the value of which remains uncertain: it is not possible to measure simultaneously the position and the velocity of a particle, or to conduct experiments regardless of the specific conditions of experimental observation. The particles of the subatomic world are not empirically present to sensation, either immediately or indirectly in the context of an idealized experiment. They are built in contingent intercourses with the measuring instrument and are observable only in the interaction with a radiation that changes the conditions of the system. As Heisenberg suggested, the material world is a web of relations that include the observer: 'what we observe is not nature itself, but nature exposed to our methods of investigation' (Heisenberg, 1959:73).

Where classical science sees permanence, fixity, and truth, contemporary science recognizes change and instability. It generates elementary particles that collide, transform into one another, and decompose. It identifies complex phenomena: quasars, pulsars, the explosion or the splitting of the galaxies, stars collapsing in blacks holes that irreversibly devour everything that falls into their trap. The claim of universality of Newtonian physics is replaced by an awareness of the relativity of an observer placed not only in the physical but also in the social and cultural world (Prigogine, Stengers, 1977).

If science results from an interaction between subject and object that produces the conditions of the system and constantly modifies them, then laboratory experiments, questionnaires, interviews and fieldwork all turn into modes of the construction of objects. The anthropological field loses its scientistic connotations of a generic, objective, and neutral container, independent of the ethnographer's practices and of relations with interlocutors. The field emerges as the effect of the ethnographers' experiences, the result of the networks of signification woven by the researchers on the basis of inter-subjective, dialogical, and pragmatic interactions (de Certeau, 1990; Gupta and Ferguson 1997). It depends on the interconnections between multiple sites and scientific communities and can subsist potentially anywhere (D'Amico-Samuels, 1991): hotels, missions, schools, cities, ships, universities, industries, refugee camps, busloads of pilgrims, scientific laboratories. This notion of the field challenges the solidity and the identity of research objects and their temporal and spatial foundations. It conceives them as complex, hybrid, mobile, emerging, multisited, circumstantial, and in constant flux (Appadurai, 1996; Canclini, 1990; Hannerz, 1992; Marcus, 1998; Rosaldo, 1989). 
By focusing on objectivation, we adopt a perspective that does not separate the theoretical from the observational, anthropological theory, or ethnographic representation: every description is already interpretive and constructive. The relation between theory and observation is subtracted from a naive empiricism. Perceptual propositions are not simply empirical but contain a knowledge: 'the echo of a thought in sight' (Wittgenstein, 1953:212). As Hanson outlines, 'seeing' is not a physical process, the formation of the retinal image, but is a 'theory-laden' enterprise (Hanson, 1958:19).

These points of view articulate the theoretical elaboration and the relationship between the particular and the general outside an inductive and subsuming logic, whose generalizing power is directly proportional to the level of abstraction and indeterminacy and in which vast and empty generalizations lose their heuristic capacity to comprehend the significance of detail. Moreover, it is logically self-contradictory to assert that two or more phenomena are universal and then to give each a specific content. As Geertz maintained, there is little benefit in saying with Herskovits that 'morality is a universal, and so is the enjoyment of beauty, and some standard of truth' if Herskovits himself is forced to add in the very next sentence that 'the many form these concepts take are but products of the particular historical experience of the societies that manifest them' (Geertz, 1973:41).

A persuasive way of elaborating generalizations that can embrace differences and contradictions beyond the limits of Aristotelian logic lies in Ludwig Wittgenstein's concept of family resemblances (Wittgenstein, 1953, §§ 66-68). Wittgenstein does not conceive of generalizations as the statistical calculations of regularities, nor does he subsume particulars under deterministic laws. His generalizations are open and uncertain, the result of abstractive processes that isolate some elements from the complexity of the empirical data and coordinate them in an ideal framework, always provisional and always open to further development. The result of this procedure, determined by the dialectic between general models and individual facts, represents the general element. It aims instrumentally at the explanation of the phenomena in their individuality, becoming a comparative criterion to which the empirical data must be related, a conceptual pre-comprehension that provides the framework for the ongoing conduct of research.

To question any appeal to rationality does not mean denying the possibility of rigorous science. It implies, rather, the recognition of multiple criteria, different from those totalizing and closed terms established by the modern conception of science. If the theory is a hypothesis that organizes the facts from a particular viewpoint, we cannot speak of verification or falsification, nor can we separate explanation from the data. Moreover, the simple accumulation of cases does not take us closer to some ultimate truth. This re-configuration of the relationship between theory and its referents also excludes the idea of a pure observational theory that can experimentally control other theories. One theory cannot falsify another for the simple reason that they are two heterogeneous and incommensurable ways of organizing the data of observation (Kuhn, 1977: 148).

The problem of validating conflicting models can, however, be articulated within the premise of hermeneutic circularity. The value of the theory depends on its ability to exhibit its object, to capture the peculiarities that validate it. The 
validation criteria refer to the coherence and agreement that the author can establish between the parts and the whole (Gadamer, 1965). What is important is the ontological power of the configuration to demonstrate, in a specific form, a possible world of objects (Ricoeur, 1983). In this horizon, truth is brought back to its original etymological meaning, as 'what it is better for us to believe' rather than as 'the accurate representation of reality' (James quoted by Rorty, 1980:10). As such it is indeed a hard truth, deeply rooted in the difficult process of its construction (Herzfeld, 2018).

The subtraction of science from the domain of truth, and of truth from the domain of method, opens spaces that allow us to combine epistemological and political critique. The perspectival nature of knowledge and the exclusion of exhaustive verifications treat the act of understanding as a moral act based on the assumption of responsibility for choosing among different conflicting models. It does not allow us to delegate such responsibilities to a necessary method, to 'reality', or to 'the people as co-authors' (Geertz, 1988:149).

This analytical reading of anthropology offers a far richer source of understanding than is possible when we surrender to scientistic attempts to supress the critical character of the research and to subtract their cultural and political character from our analyses. It attributes to science a 'sociological position' (Geertz, 1983:208), interpretable following Marx's historical materialism (Marx, 1845): 'the sciences of the ruling class are in every epoch the ruling sciences'. Or as Kuhn puts it, sciences can be thought as determined by the competition and the alternation of scientific communities, normatively defined and characterized by their mechanisms of recruitment (Kuhn, 1962).

The work of the anthropologists thus coincides with a reflection on the production and reproduction of cultural forms in the intersection between symbolic systems and the dimensions of power. It aims to deconstructs the constructions of social actors in their multiple determinations and pervasive effects: it examines who creates and who defines cultural and scientific meanings or who contingently manipulates them and for which purposes, using which traits and from which perspectives. The ethnographic analysis of these spaces of exchange probes the different positions and interests promoted by the protagonists of the various scenarios. It investigates the articulation of the constitutive elements of cultures inside complex arenas in continuous ferment where different worldviews, interests and powers connect, oppose, and collude with each other (Author, 2010).

By rejecting the sterile and paralyzing scientistic monopoly of truth, we can rethink the scientific development and social role of anthropology. These go beyond the dramatic effects produced by the use of positive and objective categories such as those marked by the public presence (Eriksen, 2006) of anthropology. This presence has historically taken many forms: from the embarrassing congruence between functionalist reifications and the pragmatism of the colonial administrations (Asad, 1973; Gough, 1968; Onoge, 1979), to participation in highly compromising action of 'development' (Flanagan, 1971; Horowitz, 1967; Kramer, 1983; McCoy, 1971; Wolf, Jorgensen, 1970) and involvement in 'Human Terrains Systems' (Forte, 2011; González, 2009; McFate and Laurence 2015; Price, 2007; Sahlins, 2007). 
Perspectives that do not involve truth and objectivity can elaborate policies open to negotiation among the various components of the polis and invite their active participation and cooperation. Evading both alarming naturalizations and identitarian clashes, these viewpoints recognize the identification - contingent, arbitrary, and artificial, and thus also fully political - of common objectives and values (Author, 2007b).

\section{Conclusion: The inter-scientific dialogue}

The multi-paradigmatic and interdisciplinary dimension of anthropological conceptual tools, the scientific roots of the discipline in the subjective experience of fieldwork, and the necessity of connecting the particular with the general, diversity with sameness, and extraneousness with familiarity turn a potential handicap into a strong resource. The assumption of opacity, contingency and precariousness as constitutive elements of the scientific effort transforms the difficulty of codifying a unique epistemology and a univocal method into the possibility of de-coding the codification itself. As Herzfeld (2018) maintains, fieldwork activity illustrates that 'objectivity' is not simply impossible but is an obstacle to the development of a 'realistic' and critical science. It constantly encourages us to rethink the scientific status of knowledge and to problematize the double link between subjectivity and objectivity, and, more generally, the complex connections among researchers, episteme, method, reality, and social actors.

The concept of objectivation links the positioning and active role of the scientist in the construction of knowledge with the non-transparency of the object as a condition and limit of knowledge. It can shape the precondition of a reflection on the interdisciplinary dialogue that surpasses the positivist monisms (old, 'neo', and new) and the historicist dualisms in favor of a unifying perspective on the relations between the sciences, albeit open, plural and contingent.

Acknowledgements Not applicable.

\section{Funding}

Not applicable.

\section{Availability of data and materials}

Data sharing is not applicable to this article as no datasets were generated or analyzed during the current study.

\section{Authors' contributions}

The author read and approved the final manuscript. 


\section{Authors' information}

RM is full professor of cultural and social anthropology, Università degli Studi di Milano-Bicocca.

\section{Ethics approval and consent to participate}

Not applicable.

\section{Consent for publication}

Not applicable.

\section{Competing interests}

The Author declares that he has no competing interests.

\section{Publisher's Note}

Springer Nature remains neutral with regard to jurisdictional claims in published maps and institutional affiliations.

\section{References}

Affergan, Francis. 1999. Construire le savoir Anthropologique. Paris: PUF.

Agar, Michael. 1985. Speaking of ethnography. London: Sage.

Appadurai, Arjun. 1996. Modernity at large: Cultural dimensions of globalization. Minneapolis: University of Minnesota Press.

Asad, Talal. 1973. Anthropology and the colonial encounter. London: Ithaca and Humanities Press.

Malighetti, Roberto. 2007a. Temporalità etnografiche: autorità autorizzazione autore. In Modelli per le scienze umane. Antropologia, scienze cognitive, sistemi complessi, ed. Silvana Borutti, 91-106. Torino: Trauben.

Malighetti, Roberto. 2007b. Politiche dell'identità. Roma: Meltemi.

Malighetti, Roberto. 2008a. O quilombo do Frechal. Identidade e trabalho de campo em una comunidade brasileira remanescente dos quilombos. Brasilia: Edições do Senado Federal.

Malighetti, Roberto. 2008b. Clifford Geertz. Il lavoro dell'antropologo. Torino: Unicopli.

Malighetti, Roberto. 2010. Identitarian Politics in the Quilombo of Frechal: Live Histories in a Brazilian Community of Slave Descendants. Outlines. Critical Practice Studies 2:97-112.

Malighetti, Roberto (马力罗). 2014a. 时间与民族志:权威、授权与作者 (Time and ethnography: authority, authorization, author) Ethno-national Studies, 民族研究 5: 49-61.

Malighetti, Roberto (马力罗). 2014b. 民族学实践：在巴西奴隶后裔社区开展的田野调查 (The ethnographic practice. Fieldwork in a Brazilian Community of Slave Descendants), 世界民族, Journal of World Peoples Studies 3:83-95.

Malighetti, Roberto Molinari Angela. 2016. Il metodo l'antropologia. Il contributo di una scienza inquieta. Milano: Raffaello Cortina Editore.

Malighetti, Roberto. (马力罗). 2018. 民族学与人类学方法论研究 (Research Methods in Ethnology and Anthropology). 北京: 知识产权出版社. 
BAAS. 1874. Notes and queries on Anthropology. London: British Association for the Advancement of Science.

BAAS. 1892. Notes and queries on Anthropology. London: British Association for the Advancement of Science.

BAAS. 1899. Notes and queries on Anthropology. London: British Association for the Advancement of Science.

BAAS. 1912. Notes and queries on Anthropology. London: British Association for the Advancement of Science.

BAAS. 1929. Notes and queries on Anthropology. London: British Association for the Advancement of Science.

BAAS. 1951. Notes and queries on Anthropology. London: British Association for the Advancement of Science.

Bachelard, Gaston. 1940. La philosophie du non. Paris: Presses Universitaires de France.

Bakhtin, Mikhail. 1986. Speech genres and other late essays. Austin: University of Texas Press.

Barley, Nigel. 1983. Adventures in a mud hut: An innocent anthropologist abroad. New York: Vanguard Press.

Beals, Alan. 1970. Gopalpur 1958-1960. In Being an anthropologist: Fieldwork in Eleven Cultures, ed. George Spindler, 32-57. New York: Holt, Rinehart and Winston.

Beattie, John. 1965. Understanding an African kingdom. New York: Holt, Rinehart and Winston.

Berger, Peter, and Thomas Luckmann. 1966. The social construction of reality: A treatise in the sociology of knowledge. New York: Anchor Books.

Bernstein, Richard. 1983. Beyond objectivism and relativism: Science, hermeneutics and praxis. Oxford: Basil Blackwell.

Berreman, Gerald. 1962. Behind Many Masks: Ethnography and Impression Management in a Himalayan Hill Village, 4. New York: Society for Applied Anthropology Monograph.

Boon, James. 1982. Other tribes, other scribes. In Symbolic Anthropology in the comparative study of cultures, histories, religions and texts. Cambridge: Cambridge University Press.

Borutti, Silvana. 1999. Filosofia delle scienze umane. Milano: Bruno Mondadori.

Bowen, Eleonore Smoth. 1954. Return to laughter. New York: Harper.

Canclini, Nestor Garcia. 1990. Culturas Hibridas: Estrategias para Entrar y Salir de la Modernidad. Bogotà: Banco de la Republica.

Carnap, Rudolf. 1935. Philosophy and logical syntax. Bristol: Thoemmes.

Casagrande, Joseph. 1960. In the company of man. In Twenty portraits of anthropological informants. New York: Haper \& Brothers.

Cassirer, Ernst. 1953. The philosophy of symbolic forms. New Haven: Yale University Press.

Clifford, James, and George Marcus. 1986. Writing culture. In The Poetics and Politics of Ethnography. Berkley: University of California Press.

Crapanzano, Vincent. 1980. Tuhami. Chicago: University of Chicago Press.

Csordas, Thomas. 1990. Embodiment as a paradigm for Anthropology. Ethos 18: 5-47.

Csordas, Thomas. 1994. Embodiment and experience. In The Existential Ground of Culture and Self. Cambridge: Cambridge University Press.

D’Amico-Samuels, Deborah. 1991. In Undoing Fieldwork. In Decolonizing Anthropology, ed. Faye Harrison, 68-87. Washington: American Anthropological Association.

Descola, Philippe. 1993. Les lances du crépuscule. Paris: Plon.

Devereux, George. 1967. From anxiety to method in the Behavioural sciences. The Hague: Mouton.

Dilthey, Wilhelm. 1883. Einleitung in die Geisteswissenschaften. Stuttgart: Nachdruck.

Droysen, Johan Gustav. 1868. Grundriß der Historik. Leipzig: Duncker and Hurnblot.

Dumont, Jean Paul. 1976. Under the Rainbow: Nature and Supernarture Among the Panaré Indians. Austin: University of Arizona Press.

Duranti, Alessandro. 1997. Linguistic Anthropology. Cambridge: University Press Cambridge.

Dwyer, Kevin. 1982. Moroccan dialogues: Anthropology in question. Baltimore: The Johns Hopkins University Press.

Epstein, Arnold. 1967. The craft of anthropology. London: Tavistock.

Eriksen, Thomas Hylland. 2006. Engaging Anthropology. The case for a public presence. Oxford: Berg.

Ernest, Paul. 1998. Social constructivism as a philosophy of mathematics. New York: State University of New York Press. 
Evans-Pritchard, Edward Evan. 1937. Witchcraft, oracles and magic among the Azande. Oxford: Clarendon Press.

Feyerabend, Paul. 1975. Against Method: Outline of an Anarchist Theory of Knowledge. New York: New left books.

Flanagan, Patrick. 1971. Imperial Anthropology: Thailand. In A Helping Hand for the Hill People. Sydney, McLeod.

Forte, Maximilian. 2011. The human terrain system and Anthropology: A review of ongoing public debate. American Anthropologist 13 (1): 145-153.

Foucault, Michel. 1971. The order of things: An archaeology of the human sciences. New York: Pantheon Books.

Gadamer, Hans George. 1965. Wahreit un Methode. Tubingen: JCB Mohr.

Geertz, Clifford. 1973. The interpretation of culture. New York: Basic Books.

Geertz, Clifford. 1983. Local knowledge. New York: Basic Books.

Giddens, Anthony. 1984. The constitution of society. Outline of the Theory of Structuration. Berkeley: University of California Press.

Glissant, Eduard. 1997. Poetics of relation. Ann Arbor: The University of Michigan Press.

González, Roberto. 2009. American counterinsurgency: Human sciences and the human terrain. Chicago: University of Chicago Press.

Goodman, Nelson. 1978. Ways of Worldmaking. Indianapolis: Hackett Publishing Company.

Gough, Kathlen. 1968. New proposals for anthropologists. Current Anthropology 9: 403-435.

Gupta, Akhil, and James Ferguson. 1997. Anthropological locations. In Boundaries and grounds for a field science. Berkeley: University of California Press.

Hannerz, Ulf. 1992. Cultural complexity. New York: Columbia University Press.

Hanson, Norwood Russel. 1958. Patterns of discovery: An inquiry into the conceptual foundations of science. Cambridge: Cambridge University Press.

Hastrup, Kirsten. 1993. The native voice and the anthropological vision. Social Anthropology 1.2: 173-186.

Heidegger, Martin. 1927. Sein und Zeit. Halle: Niemeyer.

Heidegger, Martin. 1938. Die Zeit des Weltbildes. Frankfurt Main: Klostermann.

Heisenberg, Werner. 1959. Physics and philosophy. London: Ruskin House George Allen \& Unwin Ltd..

Helmreich, Stefan. 2009. Alien Ocean: Anthropological voyages in microbial seas. Berkeley: University of California Press.

Hempel, Carl Gusrav. 1965. Aspects of scientific explanation and other essays in the philosophy of science. London: The Free Press.

Herzfeld, Michael. 2018. Anthropological realism in a scientistic age. Anthropological Theory 18 (1): $129-150$.

Horowitz, Louis. 1967. The rise and the fall of Camelot project. Cambridge, Mass: M.I.T. Press.

Ingold, Tim. 2000. The perception of the environment. New York: Routledge.

Jamin, Jean. 1986. Du Ratage comme heuristique ou l'autorité de l'ethnologue. Etudes Rurales 101-102: 337-341.

Kelly, George. 1955. The psychology of personal constructs. New York: Norton.

Kilani, Mondher. 1994. L'invention de l'autre. Lausanne: Editions Payot.

Kincheloe, Joe. 2005. Critical constructivism. New York: Peter Lang.

King, Gary. 2014. Restructuring the social sciences. Reflections from Harvard's Institute for Quantitative Social Science. Political Science and Politics 47 (1): 165-172.

Kohut, Heinz. 1984. How does analysis cure? Chicago: The University of Chicago Press.

Kramer, Fritz. 1983. Breaking Ground: Notes on the Distributions of Some Simple Tillage Tools. Sacramento: Sacramento anthropological society paper 5.

Kuhn, Thomas Samuel. 1962. The structure of scientific revolutions. Chicago: University of Chicago Press.

Kuhn, Thomas Samuel. 1977. The essential tension: Selected studies in scientific tradition and change. Chicago: University of Chicago Press.

Latour, Bruno, and Woolgar Steve. 1986. Laboratory life: The construction of scientific facts. Princeton: Princeton University Press.

Lévi-Strauss, Claude. 1958. Anthropologie structurale. Paris: Plon.

Lévi-Strauss, Claude. 1968. The scope of Anthropology. London: Jonathan Cape.

Malinowski, Bronislaw. 1922. Argonauts of the Western Pacific. London: Routledge \& Kegan Paul Ltd..

Malinowski, Bronislaw. 1967. A Diary in the Strict Sense of the term. New York: Harcourt.

Marcus, George. 1998. Ethnography through thick and thin. Princeton: Princeton University Press. 
Marx, Karl. 1845., Die deutsche Ideologie. Berlin: Marx-Engels-Gesamtausgabe .MEGA., Band I/5 1932.

McCoy, Alfred. 1971. Subcontracting counterinsurgency. Academics in Thailand. Bulletin of Concerned Asian scholars: 56-70.

McFate, Montgomery, and Laurence Janice. 2015. Social sciences Goes to war. In The human terrain system in Iraq and Afghanistan. London: C. Hurst \& Co.

Neurath, Otto. 1932. Soziologie in Physikalismus. Erkenntnis II:393-431.

Onoge, Omafume. 1979. The counter-revolutionary tradition in African states. The case of applied Anthropology. In The politics of Anthropology, ed. Gerrit Huizer, 45-66. The Hague: Mouton.

Paul, Benjiamin. 1953. Interview techniques and field relations. In Alfred Kroeber, ed. Anthropology Today, 430-451. Chicago: Chicago University Press.

Piaget, Jean. 1967. Logique et Connaissance scientifique. Paris: Encyclopédie de la Pléiade.

Pickering, Andrew. 1999. Constructing quarks: A sociological history of particle physics. Chicago: University of Chicago Press.

Price, David. 2007. Anthropology as lamppost. Anthropology Today 23 (6): 20-21.

Prigogine, Ilya and Stengers, Isabel. 1977. The new Aliance. Scientia 71: 319-332 and 617-630.

Quine, Wiliam Van Orman. 1960. Word and object. Cambridge, Mass: The Massachusset Institute of Technology Press.

Rabinow, Paul. 1977. Reflections on fieldwork in Morocco. Chicago: University of Chicago Press.

Rabinow, Paul. 1997. Making PCR: A story of biotechnology. Chicago: University of Chicago Press.

Radcliffe-Brown, Alfred Reginald. 1940. On Social Structure. The Journal of the Royal Anthropological Institute of Great Britain and Ireland 70 (1): 1-12.

Restivo, Sal. 1992. Mathematics in society and history. Dordrecht: Kluwer Academic Publishers.

Ricoeur, Paul. 1983. Temps et récit. Paris: Seuil.

Rorty, Richard. 1980. Philosophy and the Mirror of nature. Princeton: Princeton University Press.

Rosaldo, Renato. 1989. Culture and truth: The remaking of social analysis. London: Cornell University Press.

Sahlins, Marshall David. 2007. Open letter to New York times. New York Times, October 11.

Sperber, Dan. 1982. Le Savoir des Anthropologues. Paris: Hermann.

Steinmetz, George. 2005. Positivism and its others in the social sciences. In The politics of method in the human sciences, ed. George Steinmetz, 1-56. Durham: Duke University Press.

Stocking, George. 1983. Observers observed: Essays on ethnographic fieldwork. Madison: The University of Wisconsin Press.

Turnbull, Colin. 1961. The Forest people: A study of the pygmies of the Congo. New York: Simon and Schuster.

Turner, Jonathan. 1985. In defense of positivism. Sociological Theory 3: 24-30.

Tylor, Edward Burnett. 1889. On a method of investigating the development of institutions; applied to laws of marriage and descent. The Journal of the Anthropological Institute of Great Britain and Ireland 18: 245-272.

Vico, Giambattista. 1744. Principi di Scienza Nuova. Napoli: Stamperia Muziana.

Watzlawick, Paul. 1984. Invented reality: How do we know what we believe we know? New York: WW Norton.

Windelband, Wilhelm. 1894. Geschichte und Naturwissenschaft. Strassburg: Strassburger Rektoratsrede.

Wittgenstein, Ludwig. 1953. Philosophical investigations. Oxford: Basil Blackwell.

Wolf, Eric, and Joseph Jorgensen. 1970. Anthropology on the warpath in Thailand. New York Review of Books 19: 26-35. 